\section{Development of Molecular Markers Linked to Cladosporium fulvum Resistant Gene $C f-6$ in Tomato by RAPD and SSR Methods}

\author{
Aoxue Wang, ${ }^{1}$ Fanjuan Meng, ${ }^{1,2}$ Xiangyang Xu, Yong Wang, \\ and Jingfu $\mathbf{L i}^{3}$ \\ Department of Vegetable Science, College of Horticulture, Northeast \\ Agricultural University, Harbin, China 150030
}

Additional index words. tomato (Lycopersicon esculentum Mill.), Cf-6 resistant gene, Cladosporium fulvum, molecular markers

\begin{abstract}
Leaf mold, caused by the fungus Cladosporium fulvum, is a serious disease of tomato. In the current study, the main physiological races of $C$. fulvum collected from three northeastern provinces of China were identified using a set of identification hosts. The results showed that the prevalent pathogenic physiological races were 1.2.3, 1.3, 3 , 1.2.3.4, and 1.2.4. $\mathrm{F}_{1}, \mathrm{~F}_{2}$, and $\mathrm{BC}_{1}$ tomato plants were obtained by crossing $C$. fulvumresistant cultivar 03748 carrying the $C f-6$ gene and susceptible cultivar 03036 . Three 10-mer oligonucleotide random amplified polymorphic DNA (RAPD) primers and two simple sequence repeat (SSR) primers were selected for the further molecular marking analysis after 210 RAPD primers and 50 SSR primers were screened using the bulked segregate analysis method. The polymorphic DNA bands were amplified among parents, $10 F_{1}$ plants, $184 F_{2}$ plants including 145 resistant plants and 39 sensitive plants using three RAPD primers and two SSR primers so that three RAPD molecular markers and two SSR molecular markers linked to the $\boldsymbol{C f}$-6 loci were identified. Three RAPD markers were linked to the $\mathrm{Cf}-6$ resistant locus separated with $8.7 \mathrm{cM}, 20.3 \mathrm{cM}$, and $33.4 \mathrm{cM}$. Also,

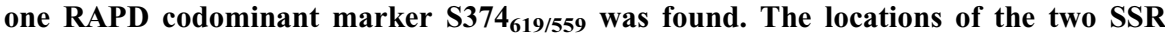
markers were $12.6 \mathrm{cM}$ and $9.7 \mathrm{cM}$ away from the $C f-6$ locus. After cloning and sequencing two specific DNA fragments closely connected to the $C f-6$ resistant and susceptible alleles respectively, in the RAPD codominant marker $S 374_{619 / 559}$ and one codominant sequence characterized amplified region marker $S 674_{619 / 559}$ was converted from RAPD marker $\mathrm{S374}_{619 / 559}$. In the RAPD marker $\mathrm{S374}_{619 / 559}$, the length difference of two specific fragments, 619-bp fragment and 559-bp fragment, is the result of one insertion $(60 \mathrm{bp})$ in the 619-bp fragment. These markers will facilitate the selection of resistant tomato germplasm containing the $C f-6$ gene and cloning of $C f-6$ to breed new C. fulvum resistant tomato cultivars.
\end{abstract}

Tomato leaf mold, caused by the fungus Cladosporium fulvum, is a serious threat to tomato production, especially on greenhouse-grown tomatoes, because it lowers both fruit yield and quality, and sometimes kills tomato plants (Thomma et al., 2005). The disease is difficult to manage because new physiological races of the pathogen can develop very rapidly (Russell, 1978; Stevens and Rick, 1986; Zhang and Cai, 1992, 1999). Fortunately, at least 24 resistant genes also have been found in some tomato germplasm that are resistant to different physiological

Received for publication 24 May 2006. Accepted for publication 25 July 2006.

This work was supported by China National " 863 " Hi-Tech Grant (2001AA241122).

We appreciate Dr. Jack Sutherland's help in reading and revising this manuscript.

${ }^{1}$ The first two authors contributed equally to this work.

${ }^{2}$ Current address: College of Life Science, Northeast Forest University, Harbin, China 150080.

${ }^{3}$ To whom reprint requests should be addressed; e-mail lijingfu_hort@yahoo.com.cn races of C. fulvum (Kanwar et al., 1980a, 1980b). Consequently, breeding to obtain resistant cultivars is an efficient method to control leaf mold outbreaks. Some of 24 resistant genes, designated $C f-1$ through $C f-24$, have been used in tomato $C$. fulvum resistant breeding to control leaf mold disease (Kerr and Bailey, 1964; Meng et al., 2005). However, according to the "gene-for-gene" principle (Flor, 1946), the use of new resistance genes accelerates the differentiation of physiological races, making it necessary to breed new resistant genes into new cultivars. This means that the status of physiological races must first be identified before a resistant germplasm breeding program can be implemented.

Also, to breed new resistant tomato cultivars, the germplasm carrying resistant genes must first be screened. Although conventional artificial inoculation can be applied in germplasm screening, it is labor intensive and time-consuming. The development of molecular markers provides the possibility of rapid screening of resistant germplasm for breeding. Moreover, molecular markers tightly linked to resistant genes also provide the basis for isolating and cloning the resistant gene. Until now, the $C f-2, C f-4, C f-4 A$, $C f-5 A$, and $C f-9$ genes have been isolated (Dixon et al., 1996; Dixon et al., 1998; Jones et al., 1994; Takken et al., 1998; Thomas et al., 1997). Fortunately, the resistance provided by the $C f-9$ gene has not been overcome by all $C$. fulvum physiological races that have been found ( $\mathrm{Du}$ et al., 1999). Although we may use the $C f-9$ gene for breeding a new tomato cultivar, physiological races of $C$. fulvum will redifferentiate after cultivars carrying the $C f-9$ gene are used, and resistant cultivars carrying the $C f-9$ gene will become susceptible to these new strains. Thus, if no germplasm carrying a new resistant gene to the new strains of C. fulvum is found, cultivars resistant to the new strains cannot be bred. Breeding for resistance is a long-term disease management strategy; the use of resistant genes depends upon the dynamics of physiological race differentiation in the field. The overuse of resistant genes leads to the breakdown of a cultivars' resistance, and we will not have the available resistant germplasm. Moreover, more than one disease-resistant gene usually can give cumulative and quantitative resistance, which can maintain resistance durability. Therefore, we must develop molecular markers linked to the other resistant genes for the screening of germplasm to get the best use of $C$. fulvum resistant genes.

In this study, we identified the main physiological races of $C$. fulvum present in three northeast provinces (Heilongjiang, Jilin, and Liaoning) of China. The $C f-6$ gene provides resistance to all prevalent physiological races of C. fulvum present in these provinces. Breeding to obtain a resistant cultivar carrying the $C f-6$ gene can satisfy the demand for controlling leaf mold disease on tomatoes in these provinces. We developed molecular markers to the $C f-6$ gene by the means of rapid amplification of polymorphic DNA (RAPD) and simple sequence repeat (SSR). These two methods, based on polymerase chain reaction (PCR), are easier, quicker, and simpler compared with the other molecular marking methods. The results should expedite the screening of tomato germplasm and provide the basis for isolating the $C f-6$ gene.

\section{Materials and Methods}

Sources and isolation of Cladosporium fulvum. Thirty-three C. fulvum-infected tomato leaves were collected from different tomato production fields or greenhouses in the Heilongjiang, Jilin, and Liaoning provinces. The leaves were stored at $-20^{\circ} \mathrm{C}$ and, before use, a $1-\mathrm{cm}^{2}$ section was cut from each infected leaf and was immersed in $70 \%$ ethanol for 2 to $4 \mathrm{~min}$, then immersed in $0.1 \% \mathrm{HgCl}_{2}$ for 3 to $5 \mathrm{~min}$ for sterilization. The sterilized tissues were incubated on potato-dextrose-agar (PDA) medium for 8 to $10 \mathrm{~d}$ and the resulting isolates of $C$. fulvum were cultured on liquid potato dextrose 
medium. Next, the fungus isolates were diluted into $10^{7}$ spores $/ \mathrm{mL}$ conidial suspensions in sterile water and spread onto PDA. Using a stereomicroscope, individual spores were transferred onto PDA media for propagation. The isolated fungi were identified based on spore shape and characters to confirm that they were C. fulvum.

Identification of physiological races of C. fulvum. The conidial suspensions were diluted to $10^{7}$ spores $/ \mathrm{mL}$ in sterile water. Tomato seedlings were inoculated by spraying conidial suspensions on the surface of leaves at the four true leaves stage. The physiological races were identified using a set of identification hosts including one series of tomato cultivars carrying different resistant genes: Money maker ( $C f-0$ gene), Leafmoud Resister ( $C f-1$ gene), Vetomold (Cf-2 gene), V121 (Cf-3 gene), Ont7516 (Cf4 gene), Ont7517 (Cf-5 gene), and Ont7519 (Cf-9 gene). Inoculated plants were immediately placed in a humidity chamber for $72 \mathrm{~h}$ at 22 to $25^{\circ} \mathrm{C}$, and then were transferred onto a greenhouse bench and again kept at 22 to $25{ }^{\circ} \mathrm{C}$. Disease severity ratings were made $15 \mathrm{~d}$ after inoculation. For analysis, the disease severity symptoms of the plants were converted to a disease score of 0 to 9 points where 0 point is no visible signs of infection; 1 point is $1-\mathrm{mm}$-diameter white spots or necrosis spots on the upper sides of leaves; 3 points is 2 to 3 -mm-diameter yellow spots on the upper sides of leaves, some white mold on the under sides of leaves, no spores formed; 5 points is 5 to 8 -mm-diameter yellow spots on the upper sides of leaves, abundant white mold on the under sides of leaves, a few spores formed; 7 points is 5 to 8 -mm-diameter yellow spots on the upper sides of leaves, some black mold, many spores on the under sides of leaves, also some black mold and no spores on the upper sides of leaves; and 9 points is masses of spores formed on both sides of the leaves. Next, physiological races were determined according to the N. Hubbeling leaf mold physiological races classification method (Hubbeling, 1971). Plants with a disease score from 0 to 3 points were classified as resistant whereas those with a score of 3 to 9 points were classified as susceptible.

Extraction of tomato total genomic DNA. Using the method of Wang and Fang (2002), $200 \mathrm{mg}$ tomato leaves were ground in liquid nitrogen with a mortar and pestle. The powder was then transferred into a $1.5-\mathrm{mL}$ centrifuge tube and preheated $800 \mu \mathrm{L}$ sodium dodecyl sulfate (SDS) extraction buffer [SDS: $10 \mathrm{~mm}$ Tris-HCl; $50 \mathrm{~mm}$ ethylenediamine tetraacetic acid (EDTA); $500 \mathrm{~mm}$ $\mathrm{NaCl} ; 10$ mм $\beta$-mercaptoethanol; $\mathrm{pH}, 8.0]$ was added and the mixture homogenized. The centrifuge tube was incubated in a water bath at $65{ }^{\circ} \mathrm{C}$ for $1.5 \mathrm{~h}$. The tube was then placed on ice immediately after incubation, $110 \mu \mathrm{NaAc}$ was added, and the tube was incubated on ice for 30 to $40 \mathrm{~min}$. Next the tubes were centrifuged at 12,000 rpm for 20 $\mathrm{min}$, the supernatant was transferred into new centrifuge tubes, and was then extracted using phenol, 1 phenol : 1 chloroform, chloroform.

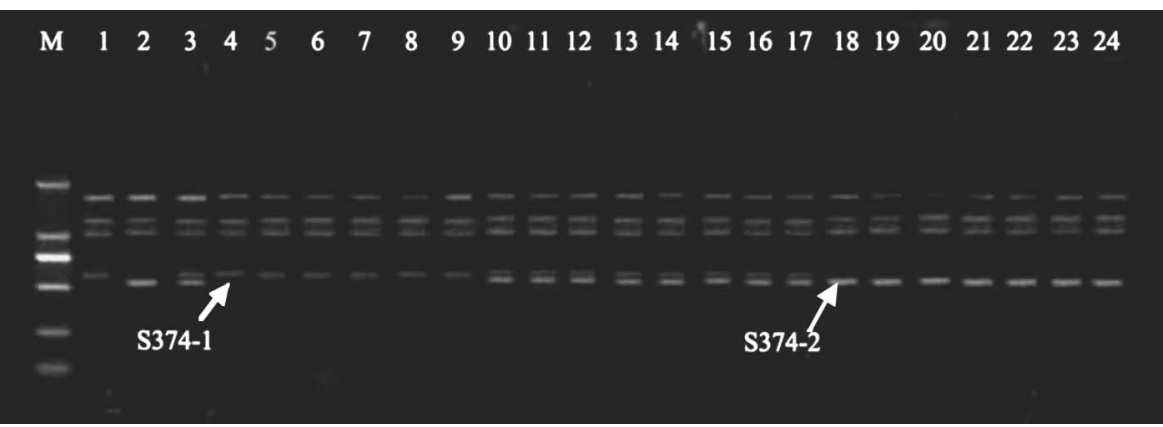

Fig. 1. The RAPD PCR amplification results using S374 primers. M, molecular weight marker; 1 , resistance parent '03748'; 2, susceptible parent '03036'; 3, $\mathrm{F}_{1}$ individual; 4-9, homozygous resistant $\mathrm{F}_{2}$ individuals; 10-17, heterozygous resistant $\mathrm{F}_{2}$ individuals; 18-24, homozygous susceptible $\mathrm{F}_{2}$ individuals.

Table 1. Genetic analysis of the Cf-6 gene in different generations.

\begin{tabular}{|c|c|c|c|c|c|}
\hline \multirow[b]{2}{*}{ Generation } & \multicolumn{3}{|c|}{ No. of plants } & \multirow{2}{*}{$\begin{array}{c}\text { The expected } \\
\text { segregation ratio }\end{array}$} & \multirow[b]{2}{*}{$\chi^{2}$} \\
\hline & Total & Resistant & $\overline{\text { Susceptible }}$ & & \\
\hline 03748 (female parent) & 10 & 10 & 0 & & \\
\hline 03036 (male parent) & 10 & 0 & 10 & & \\
\hline $\mathrm{F}_{1}$ & 10 & 10 & 0 & & \\
\hline $\mathrm{F}_{2}$ & 184 & 145 & 39 & $3: 1$ & 0.464 \\
\hline $\mathrm{BC}_{1}$ & 59 & 26 & 23 & $1: 1$ & 0.105 \\
\hline
\end{tabular}

\section{4-1 1 CCCGCTACACCTTAAACTTGAGTGCAATGAATCATTGCCTCCTTGGAGCTTCACTTGÄC}

\$374-2 1 CCCGCTACACCTTAAACTTGAGTGT--TGÄTCATTGCCTCCTTGGAGCTTCACTTGÄ

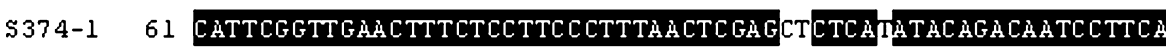

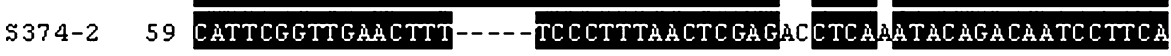

\$374-1 121 TCATGTGACC-CGTTCTCTACAACTGTAAATTGCGTTAGAGCCCCTCCTAC ${ }^{2}$ TATCCTD 5374-2 114 TCATGTGACCTCGTTCTCTACAMCTGTAMCAAGCGTTAGAGCCCСTCCTACACTATCCTC

5374-1 178 CATGÄGTTT--CACACTTCCTACAMGGTGGCCTCTCCCGAGGTTTATCAACTTTACTGT \$374-2 174 CATGÄGTTTGTCACACTTCCTACAnGG--CCTCTCCCGAGGTTTATCTACTTTACTGT

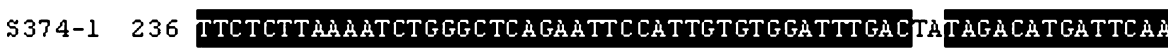
5374-2 231 TTCTCTTAMA--CTGGGCTCAGÄ--CCATTGTGTGGATTTGACATTAGACATGÄTCAA

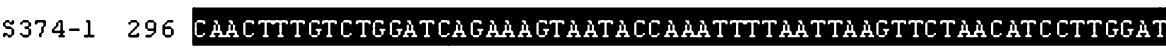

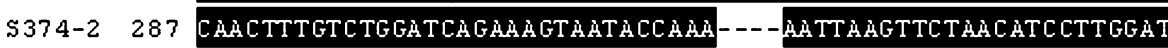

5374-1 356 GAGACTGTTÁTTGÀTCATGTGATGTTTAMATGCATAMAGAGAGAGTCATÁGTCGAMATT

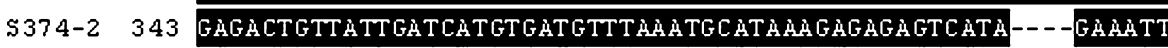

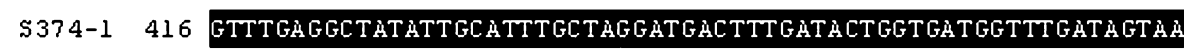
5374-2 399 GTTTGAGGCTATATTG-_.

5374-1 476 GATAATTGGATGGTGGGACTTGATGTCTGTTGATÀTAAGGÄGCGTCGACTTCCATGGÄT

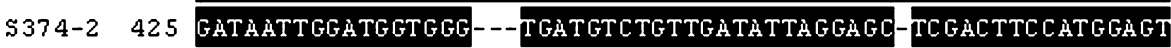

5374-1 536 CTGTGÄGÀGCATGTTGÄGGTTTGATẢCGTÁGTGTATGTGTGTATGÄGGATCCGTGCT \$374-2 481 CTGTGAGAMCATGT--AGGGTTTGATAMCGTAG-GTATGTGTGTATG---ATCAGTGCT

5374-1 596 TGGGAGATTGTGTGTAGCGGG

\$374-2 535 TGGGAGATGTGTGTAGCGGG

Fig. 2. Alignment of the nucleotide sequences of fragments S374-1 and S374-2. 
It was then precipitated with 2.5 volumes of ethanol and $1 / 5$ volume of $\mathrm{NaAc}$, centrifuged for $10 \mathrm{~min}$ at $13,000 \mathrm{rpm}$ at $4{ }^{\circ} \mathrm{C}$, and the pellet was dissolved in $40 \mu \mathrm{L}$ double-distilled water. The quantity and quality of DNA were determined at $260 \mathrm{~nm}$ and $280 \mathrm{~nm}$ using a ultraviolet spectrometer.

Plant materials. Resistant cultivar 03036 carrying the Cf- 6 gene and susceptible cultivar 03748 were maintained in the laboratory. Cultivar 03748 was pollinated using pollen from '03036' as paternal to produce $\mathrm{F}_{1}$ plants. $F_{1}$ plants were also self-pollinated to produce $\mathrm{F}_{2}$ plants. $\mathrm{F}_{1}$ plants were backcrossed with ' 03748 ' to obtain $\mathrm{BC}_{1}$. Parents, 10 of $\mathrm{F}_{1}$ plants and 184 of $F_{2}$ plants, were grown in the greenhouse at the Horticultural Experimental Station at Northeast Agricultural Univ for artificial inoculation with $C$. fulvum and molecular marking analysis. The parents, $\mathrm{F}_{1}, \mathrm{BC}_{1}$, and $\mathrm{F}_{2}$ plants were inoculated with physiological races 1.2.3.4 using the method described earlier.

Screening of RAPD and SSR primers. Bulked segregant analysis was used for RAPD and SSR primer screening according to Michelmore et al. (1991). The total genomic DNA of 10 resistant individuals and 10 susceptible individuals of the $F_{2}$ segregating population from '03036' $\times$ '03748' were pooled into the resistant and susceptible bulks respectively for screening of 216 RAPD random primers and 50 SSR primers (synthesized in Shanghai Sangon Biological Engineering Technology and Service Co. Ltd, Shanghai, China). The design of SSR primers is in accordance with tomato SSR sequences in GenBank and published elsewhere (Areshchenkova and Ganal, 1999; Bredemeijer et al., 1998, 2002; Broun and Tanksley, 1996; He et al., 2003; Smulders et al., 1997; Vosman and Arens, 1997). For RAPD analysis, PCR was conducted using a $20-\mu \mathrm{L}$ reaction system containing $200 \mu \mathrm{M}$ each of dATP, dCTP, dGTP, and dTTP; $0.2 \mu \mathrm{M}$ of a 10 -mer oligonucleotide random primer; $0.1 \mu \mathrm{g}$ template DNA; $0.5 \mathrm{U}$ Taq DNA polymerase (Fermentas); and $2 \mu \mathrm{L} 10 \times$ reaction buffer. The amplification was performed at $95{ }^{\circ} \mathrm{C}$ for $3 \mathrm{~min}$, then $94{ }^{\circ} \mathrm{C}$ for $1 \mathrm{~min}, 36{ }^{\circ} \mathrm{C}$ for $1 \mathrm{~min} 30 \mathrm{~s}, 72{ }^{\circ} \mathrm{C}$ for $5 \mathrm{~min}$ (all 35 cycles), and $72^{\circ} \mathrm{C}$ for $10 \mathrm{~min}$. For SSR analysis, PCR was executed in a $20-\mu \mathrm{L}$ reaction system containing $200 \mu \mathrm{M}$ each of dATP, dCTP, dGTP, and dTTP; $0.1 \mu \mathrm{g}$ template DNA; $0.2 \mu \mathrm{M}$ primer; $0.5 \mathrm{U}$ Taq DNA polymerase; and $2 \mu \mathrm{L} 10 \times$ reaction buffer. Amplification was conducted at $95{ }^{\circ} \mathrm{C}$ for 3 min, then $94{ }^{\circ} \mathrm{C}$ for $1 \mathrm{~min}, 55^{\circ} \mathrm{C}$ for $1 \mathrm{~min} 30 \mathrm{~s}$, $68{ }^{\circ} \mathrm{C}$ for $5 \mathrm{~min}$ (all 35 cycles), and $68{ }^{\circ} \mathrm{C}$ for $10 \mathrm{~min}$. RAPD PCR products were electrophoresed using 2\% (weight/volume) agarose gel containing ethidium bromide 1.0 $\mu \mathrm{g} \cdot \mathrm{mL}^{-1}$ in $1 \times \mathrm{TAE}(40 \mathrm{~mm}$ Tris-acetate, 1 mM EDTA) buffer, observed under ultraviolet light and photographed. SSR PCR products were separated by polyacrylamide gel electrophoresis $(6 \%$ gel $)$ and silver stained for observation (Sambrook et al., 1989).

Conversion of the sequence characterized amplified (SCAR) marker. The specific frag-
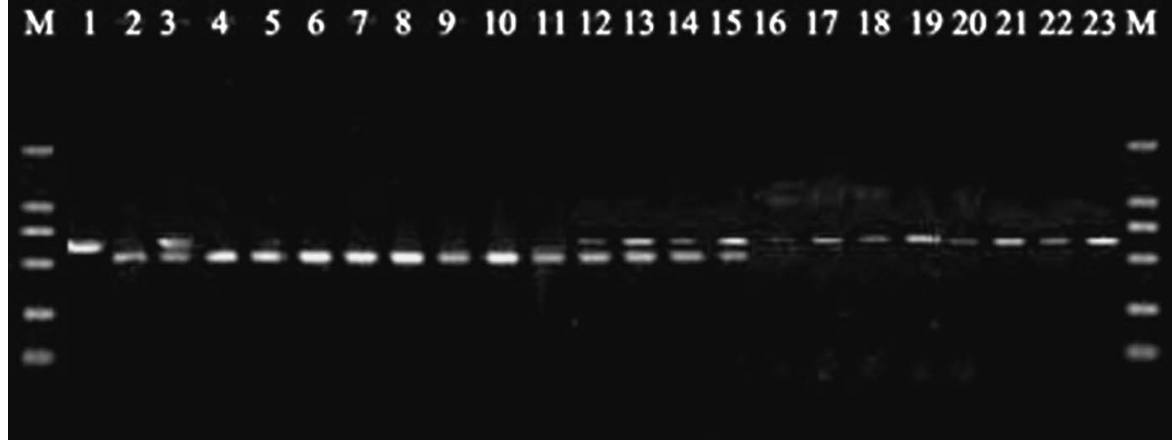

Fig. 3. The PCR amplification results with SCAR primers in the $\mathrm{F}_{2}$ population. $\mathrm{M}$, molecular weight marker (DL2000); 1, '03036' (disease-resistant parent); 2, '03748' (disease-susceptible parent); 3, $F_{1}$ individual; 4-11, disease-susceptible $F_{2}$ individuals; 12-15, heterozygous disease-resistant $\mathrm{F}_{2}$ individuals; 16-23, homozygous disease-resistant $\mathrm{F}_{2}$ individuals.

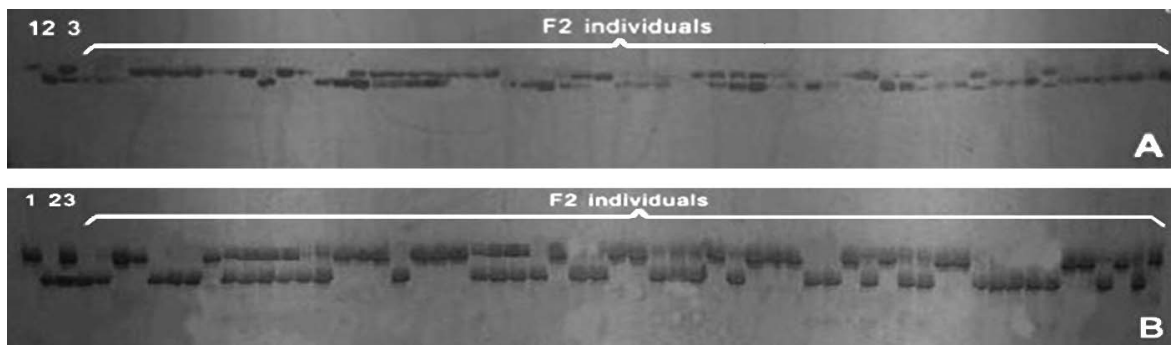

Fig. 4. The PCR amplification results with SSR primers T10 (A) and T12 (B) in the parents, $\mathrm{F}_{1}$ individuals and $\mathrm{F}_{2}$ populations. 1: '03036' (disease resistant parent); 2: '03748' (disease susceptible parent); 3: $\mathrm{F}_{1}$ individual; others: $\mathrm{F}_{2}$ individuals.

ments amplified using the S374 primer were designated S374-1 and S374-2 (Fig. 1). Fragment S374-1 was only present in resistant plants; fragment S374-2 was only produced from susceptible plants. Fragments S374-1 and S374-2 were excised from agarose gel, purified by kit (Sigma-Aldrich China, Shanghai, China) and cloned into pGEM-T easy vector [Promega (Beijing) Biotech Co., Ltd, Beijing, China] for sequencing according to the manufacturer's instructions, sequenced using the ABI PRISMTM 377 automatic sequencer using M13 sequencing primers (M13 forward primer, GTAAAACGACGGCCAGT; M13 reverse primer, CAGGAAACAGCTATGAC). The specific primers (forward primer, CCCGCTAC ACCTTAAACTT; reverse primer, GCTTGGGAGATTGTGTGTAGC) for amplifying SCAR marker S374 $619 / 559$ were designed according to the sequence of fragment S374-1. SCAR analysis was performed on 20 resistant individuals and 20 susceptible individuals from the $F_{2}$ population. PCR was conducted for an initial step of 3 min at $94^{\circ} \mathrm{C}$ followed by 40 cycles of $1 \mathrm{~min}$ at $94{ }^{\circ} \mathrm{C}, 1 \mathrm{~min}$ at $55^{\circ} \mathrm{C}, 1 \mathrm{~min}$ at $72{ }^{\circ} \mathrm{C}$, and a final step of $10 \mathrm{~min}$ at $72^{\circ} \mathrm{C}$. Agarose electrophoresis was performed as described earlier.

Data analysis. The software Mapmaker/ Exp 3.0 was used for statistical analysis of the data, and the recombination rates that were obtained were converted into genetic distance units using the Kosambi function (http://web.rhul.ac.uk/biological-sciences/ Archives/Warren/calc/mapfunc.html) (Kosambi, 1944). The genetic linkage map was drawn using Mapchart 2.1.

\section{Results and Discussion}

The identification of physiological races of C. fulvum. Thirty-three C. fulvum strains in northeast China were identified after inoculation of identification hosts. According to N. Hubbeling's C. fulvum physiological race classification method (Hubbeling, 1971), we concluded that these strains of $C$. fulvum belonged to physiological races $1.2 .3,1.3$, 3, 1.2.3.4, and 1.2.4. The results showed that all these $C$. fulvum strains were highly pathogenic to all the susceptible tomato cultivars. Based on the previous results from these three northwestern provinces ( $\mathrm{Li}$ et al., 1994), our studies show that physiological races 1.2.3.4 and 1.2.4 are new for the area. A similar situation was also found for the Beijing area in 1992 (Zhang and Fang, 1992). Our results show that some strains of $C$. fulvum have evolved into new physiological races and that the newly differentiated physiological races 1.2.3.4 and 1.2.4 have also become the dominant races. Physiological race 1.2.3.4 accounted for $57.6 \%$ of the strains that we collected whereas $24.2 \%$ of the strains were physiological race 1.2.4.

In only 9 years, the physiological races of C. fulvum have evolved into two new physiological races. Most likely this can be attributed to the widespread use of resistant cultivars and the characteristic of rapid differentiation of C. fulvum. The large-scale use of resistant cultivars leads to the redifferentiation of physiological races of C. fulvum. By physiological race identification, we used cultivar 03036, which has the $\mathrm{Cf}-6$ gene as the molecular marker, because this resistant 




Fig. 5. The genetic linkage map of RAPD markers and SSR markers, the genetic distances are shown on the left, and the name of markers are on the right. cultivar is resistant enough for all four physiological races found in these provinces. Because resistant cultivar 03036 often had a disease score of 3 points or less, a score of 3 points was set as the critical point for separating resistance and susceptibility.

Inheritance of the resistant gene Cf- 6 . Crossing resistant cultivar 03036 and susceptible cultivar $03748, \mathrm{~F}_{1}$ resulted in progeny that were resistant to all physiological races of the pathogen. By subjecting the data to chisquare analysis, we showed that the segregation ratio of resistant individuals and susceptible individuals of the $F_{2}$ population is $3: 1$. Resistant individuals and susceptible individuals of the $\mathrm{BC}_{1}$ population segregated according to the expected ratio of 1:1 (Table 1). Our results showed that the resistance of 03036 was controlled by one dominant gene and that it fits the monogenic Mendelian inheritance law. $C f-6$ is easily used in practical breeding. Also, the $C f-6$ gene may be used as a resistance gene source for gene transferring. Although $C f-6$ has been listed as a dominant gene for many years, inheritance information has been lacking. Our results also confirmed that the $C f-6$ gene is a single dominant gene.

The screening of primers and RAPD analysis for resistant gene $\mathrm{Cf}-6$. Two pairs of bulks, including resistant bulks and susceptible bulks, were screened using 21010 mer oligonucleotide primers according to the bulked segregant analyses (BSA) method. Three primers-S374, B-10, and N10 - were selected for further RAPD analysis. The parents, $10 \mathrm{~F}_{1}$ plants, and $184 \mathrm{~F}_{2}$ plants, were used for RAPD analysis. The inoculation results showed that all $\mathrm{F}_{1}$ plants were disease resistant and that 145 resistant plants and 39 susceptible plants were identified in $184 \mathrm{~F}_{2}$ plants. Two dominant markers and one codominant RAPD marker were found - namely, B-10, N-10, and S374 $619 / 559$. The 619-bp fragment (i.e., S374-1; Fig. 1), amplified using primer S374, can be only amplified in resistant cultivar 03036 and resistant bulk, but not in susceptible cultivar 03748 or the susceptible bulk. In addition, the 559-bp fragment (i.e., S374-2; Fig. 1) can only be amplified in susceptible cultivar 03748 and susceptible bulk, not in resistant cultivar 03036 and resistant bulk. All $F_{1}$ plants have two fragments whereas all $\mathrm{F}_{2}$ plants have S374-1, S374-2, or both. Obviously, the RAPD marker S374 $619 / 559$ is codominant. By RAPD PCR amplification using S374, N-01, and B-10, all bands were 500 to $2000 \mathrm{bp}$ in size. Linkage analysis showed that RAPD markers S374, N-01, and B-10 were $8.7 \mathrm{cM}, 20.3 \mathrm{cM}$, and $33.4 \mathrm{cM}$ apart from the $C f-6$ gene.

Generally, the RAPD marker is dominant. However, if insertion or deletion occurs in some regions of the marker, the RAPD marker can be codominant. This kind of RAPD marker has a codominant function like a restricted fragment length polymorphism (RFLP) marker, but less DNA is needed for the RAPD marker. Compared with the RFLP and Amplified fragment length polymorphism (AFLP) marking meth- ods, the detection process of RAPD is very rapid and easy, which is very practical for breeding selection.

Conversion of RAPD markers to SCAR markers. RAPD marker S374 mainly included two fragments: S374-1 and S374-2. The results of sequencing these two fragments showed that one insertion (34 bp) existed in the S374-1 fragment compared with the S374-2 fragment (Fig. 2). This insertion is located in the regions between 432 bp and 465 bp of the S374-1 fragment. These two fragments share $86.9 \%$ identity. To improve the specificity and stability of the RAPD marker, we converted this RAPD marker S374619/559 to SCAR marker S374 $619 / 559$. The specific primers were designed for the further confirmation of SCAR marker function in marker-assisted selection (MAS). This SCAR marker is also a codominant marker, similar to RAPD marker S374619/559, named SCAR S374 $619 / 559$, which was composed of the two specific fragments S374-1 and S374-2. Because specific primers were used as a SCAR marker, the SCAR marker was stable and was minimally affected by reaction conditions. Unlike the RAPD marker, the SCAR marker has few nonspecific bands. Therefore, the SCAR maker S374 $619 / 559$ can be more efficient in MAS for resistance.

The results of PCR amplification using SCAR primers in the $F_{2}$ population showed that the resistance of most plants was cosegregated with fragment S374-1 (Fig. 3), but several plants associated with fragment S374-2 were resistant (not shown). Although gene recombination could have occurred in this study, the probability was low. The main reason may be mainly the result of the failure of artificial inoculation, which can explain the inconsistency between the SCAR test results and host inoculation results. The SCAR markers obtained in this study need to be further confirmed in a larger population.

Screening of SSR primers and SSR analysis for resistance. The tomato SSRs were obtained in GenBank. Fifty pairs of SSR primers were designed according to the acquired simple repeat sequences. Two pairs of primers T10 (forward primer, CTGTTTACTTCAAGAAGGCTG; reverse primer, ACTTTAACTTTATTATTGCGACG) and T12 (forward primer, GAGCGAGCAGA AAGGTGAAT; reverse primer, GAGCCTGAAAACATAGAAGT) in 50 pairs of primers can produce stable polymorphic fragments between resistant bulk and susceptible bulk. The parents, $10 \mathrm{~F}_{1}$ plants, and $184 \mathrm{~F}_{2}$ plants that were used for the RAPD analysis were used for the SSR analysis. The analytical results with software Mapmaker/Exp 3.0 and the Kosambi function revealed that SSR markers T10 and T12 were linked to the $C f-6$ resistant gene with the genetic distances of $12.6 \mathrm{cM}$ and $9.7 \mathrm{cM}$ respectively. Because both these two SSR markers are located in chromosome 11 (Bredemeijer et al., 2002; Smulders et al., 1997), we concluded that the $C f-6$ gene is also located in chromosome 11. 
SSR markers have codominance characters, so resistant and susceptible cultivars have their specific fragments, and $\mathrm{F}_{1}$ individual plants have both two specific bands from the paternal and maternal cultivars. Three kinds of polymorphic bands existed in the $\mathrm{F}_{2}$ population, which represents homozygous resistant plants, homozygous susceptible plants, and heterozygous resistant plants (Fig. 4). In this study, not many simple repeat sequences of tomato were developed; consequently; we did not determine the molecular markers linked tightly to the $C f-6$ gene using the SSR method. The linkage map with the three RAPD markers and two SSR markers was obtained using Mapchart 2.1 (Fig. 5).

In conclusion, we developed RAPD and SSR markers. The genetic distances between the three RAPD markers and the $C f-6$ gene were $8.7 \mathrm{cM}, 20.3 \mathrm{cM}$. and $33.4 \mathrm{cM}$. Two SSR markers were $12.6 \mathrm{cM}$ and $9.7 \mathrm{cM}$ apart from the $C f-6$ locus. One codominant RAPD marker was converted to a SCAR marker. This is the first report of molecular markers being linked to the $C f-6$ locus. These markers can be used, for example, for molecular MAS. Because these markers are not linked very tightly to the $C f-6$ locus, they need be used for MAS along with periodic disease resistance screening to ensure result reliability. These makers can also be used for further Cf-6 marker development and map-based gene cloning.

\section{Literature Cited}

Areshchenkova, T. and M.W. Ganal. 1999. Long tomato microsatellites are predominantly associated with centromeric regions. Genome 42:536-544.

Bredemeijer, G.M.M., P. Arens, D. Wouters, D. Visser, and B. Vosman. 1998. The use of semiautomated fluorescent microsatellite analysis for tomato cultivar identification. Theor. Appl. Genet. 97:584-590.

Bredemeijer, G.M.M., R.J. Cooke, M.W. Ganal, R. Peeters, P. Isaac, Y. Noordijk, S. Rendell, J. Jackson, M.S. Röder, K. Wendehake, M. Dijcks, M. Amelaine, V. Wickaert, L. Bertrand, and B. Vosman. 2002. Construction and testing of a microsatellite database containing more than 500 tomato varieties. Theor. Appl. Genet. 105:1019-1026.
Broun, P. and S.D. Tanksley. 1996. Characterization and genetic mapping of simple repeat sequences in the tomato genome. Theor. Appl. Genet. 250:39-49.

Dixon, M.S., D.A. Jones, J.S. Keddie, C.M. Thomas, K. Harrison, and J.D.G. Jones. 1996. The tomato Cf-2 disease resistance locus comprises two functional genes encoding leucinerich repeat proteins. Cell 96:451-459.

Dixon, M.S., K. Hatzixanthis, D.A. Jones, K. Harrison, and J.D.G. Jones. 1998. The tomato $C f-5$ disease resistance gene and six homologs show pronounced allelic variation in leucinerich repeat copy number. Plant Cell 10:19151925.

Du, Y., Z. Yan, X. Wang, and S. Li. 1999. Recent advances in tomato breeding. Acta Hort. Sinica. 26:161-169. (in Chinese).

Flor, H.H. 1946. Genetics of pathogenicity in Melampsora lini. J. Agr. Res. 73:335-357.

He, C., V. Poysa, and K. Yu. 2003. Development and characterization of simple sequence repeat (SSR) markers and their use in determining relationships among Lycopersicon esculentum cultivars. Theor. Appl. Genet. 106:363-373.

Hubbeling, N. 1971. Determination trouble with new races of Cladosporium fulvum Cooke. Meded. Rijksfac. Landbouwwet. Gent. 36:300-305.

Jones, D.A., C.M. Thomas, K.E. HammondKosack, P.J. Balint-Kurti, and J.D.J. Jons. 1994 Isolation of the tomato $\mathrm{Cf}-9$ gene for resistance to Cladosporium fulvum by transposon tagging. Science 266:789-793.

Kanwar, J.S., E.A. Kerr, and P.M. Harney. 1980a Linkage of Cfl to Cfll genes for resistance to leaf mold Cladosporiumfulvum Cke. Rep. Tomato Genet. Coop. 30:20-21.

Kanwar, J.S., E.A. Kerr, and P.M. Harney. 1980 b. Linkage of $\mathrm{Cfl} 2$ to $\mathrm{Cf} 24$ genes for resistance to leaf mold Cladosporiumfulvum Cke. Rep. Tomato Genet. Coop. 30:22-23.

Kerr, E.A. and D.L. Bailey. 1964. Resistance to Cladosporium fulvum Cke obtained from wild species of tomato. Can. J. Bot. 42:1541-1554.

Kosambi, D.D. 1944. The estimation of map distances from recombination values. Ann. Eugen. 12:172-175.

Li, G., J. Li, Y. Li, Q. Guo, and F. Wang. 1994. The preliminary studies on the differentiation of Cladosporium fulvumin 3 northeastern provinces of China. J. Northeast Agr. Univ. 25, 122 125. (in Chinese).

Meng, F., X. Xu, and J. Li. 2005. The progress on resistance breeding of tomato leaf mold disease. Chin. Agr. Sci. Bull. 21:297-301. (in Chinese).

Michelmore, R.W., I. Paran, and R.V. Kesseli. 1991. Identification of markers linked to dis- ease-resistance genes by bulked segregant analyses: A rapid method to detect markers in specific genomic regions by using segregating populations. Proc. Natl. Acad. USA. 88:98289852.

Russell, G.E. 1978. Leaf mould, p. 133-136. In: D.J.A. Cole, W. Haresign, J.P. Hudson, G.E Russell, and D.E. Tribe (eds.). Plant breeding for pest and disease resistance Butterworths, London.

Sambrook, J., E.F. Fritsch, and T. Maniatis. 1989 Molecular cloning: A laboratory manual. 2nd ed. Cold Spring Harbor Laboratory Press, Cold Spring Harbor, N.Y.

Smulders, M.J.M., G. Bredemeijer, W. Rus-Kortekaas, P. Arens, and B. Vosman. 1997. Use of short microsatellites from database sequences to generate polymorphisms among Lycopersicon esculentum cultivars and accessions of other Lycopersicon species. Theor. Appl. Genet. 97:264-272.

Stevens, M.A. and C.M. Rick. 1986. Genetics and breeding, p. 67-68. In: J.G. Atherton and J. Rudich (eds.). The tomato crop. Chapman and Hall, London.

Takken, F.L.W., D. Schipper, H.J.J. Nijkamp, and J. Hille. 1998. Identification and Ds-tagged isolation of a new gene at the Cf-4 locus of tomato involved in disease resistance to $\mathrm{Cla}$ dosporium fulvum race 5. Plant J. 14:401-411.

Thomas, C.M., D.A. Jones, M. Parniske, K. Harrison, P.J. Balint-Kurti, K. Hatzixanthis, and J.D.G. Jones. 1997. Characterization of the tomato $\mathrm{Cf}-4$ gene for resistance to Cladosporium fulvum identifies sequences that determine recognitional specificity in Cf-4 and Cf-9. Plant Cell 9:2209-2224.

Thomma, B.P.H.J., H.P. van Esse, P.W. Crous, and P.J.G.M. de Wit. 2005. Cladosporium fulvum (syn. Passalora fulva), a highly specialized plant pathogen as a model for functional studies on plant pathogenic Mycosphaerellaceae. Mol. Plant Pathol. 6:379-393.

Vosman, B. and P. Arens. 1997. Molecular characterization of GATA/GACA microsatellite repeats in tomato. Genome 40:25-33.

Wang, G. and H. Fang. 2002. Plant gene engineering, p.742-744. 2nd ed. China Science Press, Beijing. (in Chinese).

Zhang, H. and M. Cai. 1992. The studies on the redifferentiation of tomato leaf mold physiological races in Beijing area. China Vegetable. 2:1-3. (in Chinese).

Zhang, H. and M. Cai. 1999. Studies on physiological races of tomato leaf mould and their differentiation in Beijing. Acta Agr. BorealiSinica. 14:113-118. (in Chinese). 